In elucidating the obscure religious beliefs, with the extensive system of divine beings, Mr. Evans arrives at the conclusion that these are ancestors; but he makes the interesting and instructive suggestion that the explanation given of the origin of these divine beings-that they were the individuals who escaped to heaven and became deities because their hair had not been frizzed in the battle between the monkeys-may be derived from the Ramayana. Attention may be directed also to his remarkable and fortunate record of the shaman in action, an interesting and important matter on which little or nothing in detail was known previously. Mr. Evans was the first European to be present at a shamanistic per- formance and the first to describe the shaman's hut.

On the broader question of the ethnological position of the Negritos, Mr. Evans has little to add to what has been said by others. From his archæological investigations, however, he makes one important contribution. In relation to the question whether the pygmy people represent the earliest entrants into the Peninsula, he points out that the skeletal remains of the inhabitants of the caves belonging to the palæolithic-neolithic transition period investigated by him were not those of a Negrito type, and that this type does not appear until relatively late in the archæological succession.

\title{
Culture-Contact in India
}

A Tribe in Transition:

a Study in Culture Pattern. By Dr. D. N. Majumdar. Pp. $x i+216+5$ plates. (Calcutta, London, New York and Toronto: Longmans, Green and Co., Ltd., 1937.) 10s. 6d. net.

$D^{\mathrm{P}}$ R. MAJUMDAR'S book aims at doing something more than merely giving us an account of the Hos of the Kolhan. This indeed he does not neglect, but his particular purpose is to show them as they have reacted and continue to react to the effects of contacts with their Hindu neighbours. He states as his methodological ideal a synthesis of Malinowski's approach in "The Argonauts" with that of Ruth Benedict in "Patterns of Culture", but his adherence to their methods is by no means overstressed. He gives a comprehensive account of the social culture of the Ho, who clearly retain a very great deal of their typical culture in spite of their many contacts with Hinduism, which have influenced in particular their marriage ceremonies and festivals.

Dr. Majumdar seems inclined to accept the view that the Ho originally migrated southwards from the Himalayas. $\mathrm{He}$ mentions that the language used in spells is non-Austric, but does not specify what language actually is used. Vestiges of totemism seem to exist, though repudiated as such by the author, and there has clearly been a megalithic cult, now so generally decadent that menhirs do not seem to be erected at all, though horizontal slabs of stone are still provided for the dead.

The institution of bachelors' dormitories is considered as definitely fostering homosexuality, and this is remarkable, since generally speaking the bachelors' dormitory system, both in Assam and in
Chota Nagpur, does not seem to have that effect at all. One's confidence in the author is rather severely shaken by finding that he imputes the custom of marriage by capture to the Naga Hills, and he is surely wrong in supposing that the claim on the part of a married woman's patrilineal family to the half of her bones is something new, unless it is in their not demanding the whole. The custom of returning the woman's bones to her own clan is the more ancient, and in a Munda marriage there is always a formal stipulation by the bride's clan that the bones shall be returned, although it is not really intended by either party that the promise to do so shall be implemented ; in Assam a 'bone-price' is paid as a quittance for the obliga. tion to return them.

Zoological references are obscure and the Latin names unfamiliar: the corsac fox is surely not the one usually found in India, which is more familiar as Vulpes bengalensis than as Cynalopex insectivorus ; the sambar (referred to as "saumer") is generally classified as Rusa, not as Cervus by genus, and one is left guessing what is meant by "grower" and by "red deer". A map is very badly needed, and likewise a glossary to explain to the English reader such words as birdiring, ficca, sonta or hatu. Material culture is poorly treated; tattooing is mentioned, but pigments and processes are not described; and with no illustrations to help one the descriptions of objects (for example, of a plough on p. 6) are very difficult indeed to follow. On the whole, however, the book is an important contribution to Indian ethnography, particularly in its estimate of the impact of Hinduism on the culture of the Hos, and marks a rather new departure in Indian ethnographical literature.
J. H. H. 